\title{
Gemilerin Özdeș Rota ve Menzile Yaptikları Seferlerin Maliyetine Etki Eden Faktörlerin Analizi
}

Elif BAL BEȘiKçi' - Aydın ȘIHMANTEPE²

Makale Gönderim Tarihi: 29.11.2019

Makale Kabul Tarihi: 16.03.2020

\section{Öz}

Bu çalıșmada; gemilerin sefer maliyetlerini olușturan kalemler çözümlenmiștir. Çalıșmada, sefer maliyetlerini çözümlemek üzere, tarifeli (layner) çalıșan bir geminin aynı rotaları kullanarak aynı limana yaptığı üç farklı seferdeki giderleri karșılaștırılarak sonuçlara varılmıștır. Seferlere ilișkin maliyetler incelenirken sefer maliyetini en çok etkileyen harcamaların hangi kalemler olduğu üzerinde durulmuștur. İnceleme, sefer maliyetlerinin geminin süratinden ve hava/deniz koșullarından doğrudan etkilenen yakıt giderleri kadar, bir kerede tașınan yüklerin çeșitliliğinin artmasıyla yükleme/tahliye zamanlarının uzamasından kaynaklandığını ortaya koymuștur. Farklılıkların bunun dıșında geminin demirde ve boğaz ağzı gibi bölgelerde atıl olarak beklediği sürelerden de kaynaklandığı tespit edilmiștir.

Anahtar Kelimeler: Gemi Sefer Maliyetleri, Layner Tașımacılık, Tanker Gemisi

JEL Siniflaması: F23, L25, L91, L92

(Sorumlu yazar) Dr. Öğr. Üyesi, İstanbul Teknik Üniversitesi, Denizcilik Fakültesi, Deniz Ulaștırma İșletme Mühendisliği Bölümü, Orcid ID: 0000-0002-7882-8292

2 Dr. Öğr. Üyesi, Piri Reis Üniversitesi, Denizcilik Fakültesi, Deniz Ulaștırma İșletme Mühendisliği Bölümü, Orcid ID: 0000-0002-3781-1806 


\section{Analysis of Factors Affecting Identical Route and Range Voyage Costs}

\section{Abstract}

This study focuses on analysis of items that affect ships' voyage costs. Investigation is performed by deconstructing and comparing voyage costs of three identical voyages of the same liner ship. The focus is directed on the items that affect the costs significantly. It is assessed that voyage costs are affected by the increase in the variety of cargo and hence extended handling times as well as fuel consumption, which is directly influenced by the ship speed and sea/weather conditions. The differences in costs proved to source also from waiting times at strait entrance and anchorage areas.

Keywords: Ship Voyage Costs, Liner Shipping, Tanker Vessel JEL Classification: F23, L25, L91, L92

\section{Giriș}

Günümüzde uluslararası ticaretin büyük bir bölümü deniz yoluyla gerçekleștirilirken, deniz tașımacılığının önemi de ticaretin küreselleșmesine paralel olarak giderek artmaktadır. 2017 yılına kadar küresel ticaretin hacim olarak yüzde 80'inden, değer olarak ise yüzde 70'inden fazlası deniz yolu tașımacılığı ile yapılarak tașınan mallar dünyanın her tarafında yaygın ağ olușturmuș olan liman tesisleri tarafından ișleme alınmaktaydı. (United Nations Conference on Trade and Development (UNCTAD), 2017). UNCTAD'ın tahminlerine göre, 2017 ve 2022 yılları arasında deniz tașımacılığının hacmi öngörülen yıllık bileșik büyüme oranı açısından 3.2 oranında artmaya devam edecektir.

Tașımacılık sektöründe bulunmak önemli bir iș potansiyeli sunarken aynı zamanda operasyonel ve finansal riski de beraberinde getirmektedir. Bunların içinde bir denizcilik firması için belki de en önemli risk kaynağını, tașıma ücretlerindeki değișikliğe doğrudan bağlı olan navlun ücreti riski olușturmaktadır. Bu riskin olușmasının temel nedeni, navlun piyasasındaki olası bir dalgalanmanın șirketin karlılığı üzerinde doğrudan etkide bulunuyor olmasıdır. Bir diğer önemli etki de, șirketin varlıklarının (gemilerin) değer dalgalanmasından kaynaklanan ve varlık değeri riski olarak adlandırılan risk etkisidir (Alizadeh ve Nomikos, 2012). Bu tür dalgalanmalar, bir șirketin borç ve yükümlülükleri ile doğrudan etkileșimde olduğu için, șirketin sadece kaydedilmiș değeri 
üzerinde değil, aynı zamanda o șirketin kredi itibarı üzerinde de etki yapar. Gemide tüketilen yakııın toplam seyir maliyetinin ortalamada yüzde 60-70'inden fazlasını olușturduğu dikkate alındığında, yakıt fiyatlarındaki dalgalanmaların da șirketin karlılık marjlarını doğrudan etkilediğini söylemek yerinde olacaktır (Alexandridis ve diğerleri, 2018).

Günümüzde denizcilik șirketleri küresel boyutta etkileșim içerisinde bulunarak, yașanan hızlı değișimlere ayak uydurmak zorundadırlar. Beklenmedik karmașık durumların aniden belirebildiği bu küresel piyasada çalıșmanın zorluklarıyla da baș etmek durumundalar. Bir șirket açısından maliyet, o șirketin piyasadaki rekabet edebilme gücünü doğrudan etkileyen en önemli faktörlerden birini olușturmaktadır. Bu nedenle bir gemi ișletmesi karını maksimize edebilmek için gider olarak görünen bütün kalemleri yakından takip ederek kontrol altına almalıdır (Esmer ve diğerleri, 2005). Tașımacılıktan elde edilen kârı artırmanın iki ana unsurunu ișletme maliyetlerinin azaltılması ve navlun gelirinin artırılması olușturur. İșletme maliyeti, gemi yakıtının maliyeti ile diğer bazı görece sabit masrafları (liman ücretleri, personel giderleri, sigorta, idari harcamalar bakım ve onarım vb.) içerir (Notteboom, 2006). Ronen (2011), Golias ve diğerleri (2009) ve Notteboom (2006)'e göre gemi yakıtı genel olarak toplam ișletme maliyetinin yüze 50'sini hatta bazen yüzde 75'inden fazlasını olușturabilmektedir. Yakıt fiyatlarındaki ya da yakıt tüketimindeki küçük değișiklikler gemi yakıt maliyetlerinde büyük değișikliklere neden olabilmektedir (Wang ve diğerleri, 2019).

Deniz tașımacılığı birçok farklı açıdan sınıflandırılabilir. Kargo tiplerine bağlı olarak yapılan en yaygın sınıflandırmaların bașında layner (tarifeli/düzenli) ve tramp (tarifesiz/düzensiz) hat tașımacılığı gelir (Erol, 2016). Tarifeye dayalı (layner) tașımacılıkta mallar yüksek kapasiteli gemiler tarafından düzenli rotalar üzerinde sabit zaman çizelgeleri ile tașınır (Wang ve Meng, 2012). Buna karșın deniz tașımacılığında dökme yükler daha çok tarifesiz tașımacılık tarafından gerçekleștirilir (Erol, 2013). Layner tașımacılıktan farklı olarak tarifesiz tașımacılık; belirli bir rotası (tașıma hattı) ya da zaman çizelgesi olmayan, malları farklı varıș noktaları arasında tașımaya uygun olan bir hizmet șeklini ifade eder (Trivedi, 2010).

Tarifesiz ticarette, deniz tașımacılığı șirketleri gemilerini sabit belirli rotalar ve zaman çizelgeleri üzerinden yönlendiremezler. Cü̈nkü tarifesiz tașımacılığın en belirli özelliği zaman ve rotaların düzenli olmayıșıdır. Bu nedenle tarifesiz tașımacılıkta maliyet yapısı firmadan firmaya, 
gemiden gemiye değișebilir. Bu tür tașımacılıkta tüm maliyetler sefere özel olarak hesaplanır ve her bir farklı sefer için bu maliyet hesabı yeniden yapılmak durumunda kalınır (Altug, 1974; Çakı, 1998). İs yükünün de artmasına neden olan bu ișleyiște, her bir geminin ve her bir seferin muhasebe ve masraf kayıtlarının farklı bir girdi olarak tutulması gerekir (Ozdemir, 2009). Her bir seferin maliyet yapısını ayrı ayrı hesaplamak zorunda kalan gemi yöneticileri o seferin navlun gelirine bakarak tașıma ișlemini yapıp yapmamaya karar verir. Bu tür çetin rekabet ortamına sahip sektörlerdeki iș yöneticilerinin seçebileceği en önemli stratejiyi iște bu maliyet odaklı yöntem olușturur (Karcıoglu, 2000). Bu nedenle maliyet yapısını ve satılan tașıma hizmetinin maliyet bileșenlerinin bilinmesi ihtiyaç duyulur.

Bu çalıșma, layner tașımacılık yapan gemilerin sefer maliyetlerini olușturan gider kalemlerinin mukayeseli olarak çözümlenmesini hedeflemiștir. Çözümleme sırasında sefer maliyetine ilișkin giderler büyüklük ve denizcilik ișletmesi tarafından kontrol edilebilirliği yönüyle incelenmiștir.

Çalıșmada, sefer maliyetlerini çözümlemek üzere, layner çalıșan bir geminin aynı rotaları kullanarak aynı limana yaptığı özdeș üç farklı sefer incelenmiș, ortaya çıkarılan sefer giderleri karșılaștırılarak her kalem giderin sefer maliyeti üzerindeki etkileri tespit edilmiștir. Seferlere ilișkin maliyetler incelenirken, sefer maliyetini en çok etkileyen harcamaların hangi kalemler olduğu üzerinde durulmuștur. Bununla birlikte, sabit ve ișletme tarafından değiștirilemeyen giderlerin bir listesi olușturulmuș, kontrol edilebilir ve değișken unsurların sefer maliyetine etkileri açısından karșılaștırılmıștır.

Çalıșmanın devamında gemi sefer maliyetine ilișkin temel kavramlar detaylı olarak Bölüm 2'de sunulmuștur. Bölüm 3'te çalıșmada kullanılan örnek gemiye ilișkin gemi bilgileri, sefer bilgileri, yakıt harcama bilgileri ve sefer maliyetinin sabit ve değișken kalemlerine ait bilgiler yer almaktadır. Bölüm 4'de örnek geminin farklı seferlerine ait verilerin mukayesesinden çıkarılan bulgular değerlendirilmiștir. Sonuç bölümünde ise yapılan değerlendirmelere paralel önerilerde bulunulmuștur.

\section{Gemi Sefer Maliyetleri}

Gemilere ilișkin ișletme maliyetlerine bakıldığında bunların en genel anlamda sabit giderler ve değișken giderler olarak iki ana kısma ayrıldığı görülmektedir (Esmer, 2005; Incaz, 2017). Sabit giderler konusunda ișletmecilerin müdahale edebilecekleri fazla bir kalem bulun- 
mamaktadır. Buna karșın değișken olarak nitelenen giderlerin optimum seviyelerde olacak șekilde müdahalede bulunulması geminin navlun gelirlerinin artması sonucunu getirecektir (Esmer, 2005).

Değișken maliyet olarak tanımlanan kalemler, faaliyetin büyüklüğündeki değișimlere orantılı olacak șekilde paralel olarak artan maliyetleri içermektedir (Garrison ve Noreen, 2000). Bir mal veya alınan hizmete ilișkin değișen maliyetleri doğrudan o mal ve hizmete ödenen ücretler olușturur. Öte yandan sabit maliyet kalemleri belirlenen bir dönem içinde, faaliyetin büyüklüğünden bağımsız olarak sabit kalan, amortisman, kira giderleri, sigorta ödemeleri gibi maliyetleri içermektedir (Bursal ve Ercan, 2000; Rayburn, 1996). Belirlenen bir zaman dilimi içinde sabit maliyetlerin tutarı ve toplamı ișletme yöneticilerince bir dereceye kadar öngörülebilir.

Tașımacılık maliyetleri (Everett ve Boris, 1994; Stopford, 1997) așağıdaki dört ana kategoride sınıflandııılır: (i) ișletme maliyetleri, (ii) sefer maliyetleri, (iii) yük elleçleme maliyetleri ve (iv) sermaye maliyetleri. Maliyet analizi yapmak için yukarıda sayılan maliyet kategorilerinin her birinin hesaba katılması önerilmektedir. Geminin ișletilmesine ne dereceye kadar müdahil olduğu ve ödemekle yükümlü olduğu ișletme, sefer, yük elleçleme ve sermaye maliyetleri dikkate alınarak gemi sahibinin kazançta bulunacağı farklı seçenekler olușturulabilir (Khan ve Abed, 2010).

Burada üzerinde durulması gereken nokta, sefer maliyetlerinin, geminin yapacağı sefere bağlı olarak tașıyacağı yük için yapması zorunlu olan giderlerden olușuyor olduğu gerçeğidir. Bu maliyetler; sefer için harcanan yakıta ilișkin giderler, kanal/boğaz geçiș giderleri, liman vergi ve ücretleri, kullanılan acente hizmetleri karșılığında ödenen meblağlar, kılavuzluk ve römork hizmetleri bedelleri gibi ücretlerinden olușmaktadır (Arslan ve Gürel, 2008). Buna karșılık sermayeye ilișkin maliyetler, șirketin yatırımlarını veya yaptığı etkinlikleri finanse etmek için kullanmakta olduğu sermayesini (borç veya öz sermaye olabilir), dağıtılmayan kâr paylarını ve hisse senetleri için ödenen miktarlar ile kullandığı fonlar nedeniyle yatırımcıya ödenmek durumunda olan bedellerin tümünü kapsar (Okka, 2009). Öte yandan ișletme maliyetleri de geminin günlük olarak çalıștırılmasıyla ilgili olan ve geminin her an seyre hazırlıklı olarak idame ettirilmesi için süregelen harcamaları içerir (Downard, 1982). Yük elleçleme maliyetleri ise terminal ücretleri ve kar- 
goya ilișkin ileri sürülen taleplerden olușur. Șekil 1 gemi sefer maliyetini olușturan ana harcama giderlerini göstermektedir.

Șekil 1: Gemi sefer maliyetleri (Esmer, 2005)

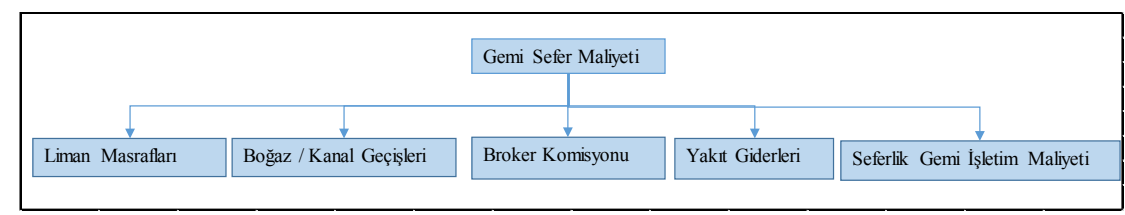

\subsection{Liman Masrafları}

Liman giderleri geminin uğradığı limanların sayısı, limanlarda kaIınan süre ve kullanılan hizmetlere bağlı olarak değișir. Bu masraflar, alınan kılavuzluk hizmetleri, palamar, demirleme, șamandıra ve barınma ücretleridir. Bununla birlikte, fener, rıhtım, sağlık depo/antrepo, karantina, sağlık ücretleri ile gidilen yere bağlı olarak kanal harçları ve diğer resim harç ve vergiler de liman masrafları içinde yer alır (Alııbuçuk, 2000).

Liman masrafları gemi büyüklüğüne bağlı olarak artıș gösterir. Limanlarda sağlanan hizmetler yüke ilișkin ve gemiye ilișkin hizmetler olarak iki ana grupta toplanır (Çatak, 2003). Gemiye ilișkin olanları özetle: (i) kılavuzluk ve römork hizmetleri, (ii) barınma hizmetleri, (iii) atıkların alınması hizmeti, (iv) içme suyu ikmali hizmetleri olușturur. Yüke ilișkin hizmetler ise: (i) yükleme ve boșaltma, ( ii) yer değiștirme (shifting) ve aktarma (limbo), (iii) terminal ve depo hizmetlerinden olușur (Özdemir, 2009).

\subsection{Boğaz/ Kanal Geçiș Masrafları}

Deniz tașımacılığının bazı rotalarında kat edilen mesafeyi önemli ölçüde azaltan suyolları kullanılır. Süveyș Kanalı ile Panama Kanalı bu kestirme suyollarının en bașta gelen örnekleridir. İstanbul ve Çanakkale Boğazları da alternatifleri olmayan önemli boğazlara örnek oluștururlar. Bu tür kanal ve boğazların ticaret gemilerince kullanılmasında, yerel otoritelerce belirlenerek ilan edilmiș olan ve gemi büyüklüğüne bağlı olarak değișen geçiș ücretlerinin ödenmesi gereklidir. Bu ücretlere ilave olarak, geçiș sırasında faydalanılan acente hizmetlerine ödenen bedeller de masrafların bir bölümünü olușturur. 


\subsection{Komisyon}

Tașınacak yük ile tașıyıcı gemiyi bir araya getiren, bununla birlikte hem tașıtanın hem de tașıyıcının karșılașabileceği olası problemleri çözmeyi üstlenen kurulușlar navlun komisyoncuları (broker) olarak adlandırılırlar. Bu kurulușlar, bir yandan gemicilik ișletmelerine yük, tașiııcıya da uygun nitelikteki gemiyi sağlamaya çalıșırken, diğer yandan hem tașıyıcıyı piyasaya tanıtarak orada yer edinmesini sağlar, hem de yük sahibine tașıyıcı hakkında ihtiyaç duyacağı bilgileri temin ederler. Navlun komisyoncuları tașıyıcı ve tașııııı arasındaki bağlantıyı sağladıkları zaman, hizmet satıșını gerçekleștirmiș olurlar ve bağlantısını yaptıkları navlun üzerinden komisyon ücreti alırlar (Eröztürk, 1985). Bu tür kurulușlar ișin doğası gereği daha çok tarifesiz (tramp) tașımacilıkta etkin olarak çalıșırlar ve hem tașıyan hem de tașıtana karșı sorumlulukları vardır.

\subsection{Yakıt Gideri}

Sefer maliyetinin \%50'sini olușturan yakıt, personel maașlarından dahi büyük bir maliyet olarak gemilerin operasyon maliyetlerindeki en büyük kalemi olușturmaktadır (Stopford, 2009). Petrol fiyatlarında 1970 -1980 yılları arasında yașanan büyük artıș (yaklașık 10 kat), yüksek yakıt tüketimine sahip gemilerin boșta bekletilmesine neden olmuștu. 1985-2000 yılları arasında petrol fiyatlarına yașanan düșüss, denizcilik sektöründe enerii verimliliği konusundaki araștırma ve geliștirme çabalarının ön plana çıkmasına izin vermedi. Ancak 2000 yllından sonra ham petrol fiyatlarında yașanan tırmanıș, gemi makinaları üreticileri, tersaneler ve gemi tasarımcılarının, gerek tasarım gerekse azaltılmıș yakıt tüketimi ve enerii verimliliği yeniden yatııım yapmalarına neden olmuștur (Bialystocki ve Konovessis, 2016).

Gemi yakıı fiyatları, uluslararası piyasalardaki yașanan petrol ve petrol ürünleri fiyatlarındaki değișime koșut olarak değișim göstermektedir. Bu durumda yakıt fiyatlarının ne yönde değișeceğini kestirmek güç olmaktadır. Bunun yanı sıra uluslararası sefer yapan gemilerin aldıkları yakııı fiyatı ülkelere ve limanlara göre değișiklik göstermesi de yakıt harcamalarını doğrudan etkilemektedir. Bu açıdan bakıldığında, yakıın nereden alındığının da yakıt maliyetini etkileyen önemli bir etken olduğu görülmektedir. Diğer bir deyișle yakıt ikmaline ilișkin bir strateji geliștirmek de yakıt giderlerini düșürmek için önem arz etmektedir (Wang ve diğerleri, 2019). 
Deniz tașımacılığında yakıt ve yağlama yağı maliyetlerinin tamamı bunker maliyetleri olarak adlandırılır ve bu maliyet gemi tipi ve büyüklüğüne bağlı olarak değișir. Bu maliyeti teknik olarak etkileyen faktörlerin bașında gemi ana makinesinin tipi, yașı, kilovatt olarak gücü, makinede yakılan yakıtın türü (HFO Heavy Fuel Oil, Marine Diesel Oil vs.) gelmektedir. Bu maliyet, gemi sefere çıkmadığı durumlarda en az seviyede seyreder fakat geminin liman durumda olduğu zamanlarda dahi elektriğ in üretilmesi, havalandırma, soğutma ve ısıtma sistemlerinin çalıștırılması gerekeceğinden, devrede olan yardımcı sistemleri nedeniyle sıfıra düșmez.

Gemi seyir halindeyken toplam bunker gideri geminin sürati ve buna karșılık makinenin harcadığı yakıt miktarıyla birlikte, gemi kaptanının, bașmühendisinin ve diğer personelin tecrübe ve dikkatine de bağlıdır. Etkileyen diğer faktörler arasında hava ve deniz koșulları, geminin seyir süresince sahip olduğu trim ve draftı ile makinelerin yașı da bulunur. Yine de bunker maliyetindeki en önemli unsur geminin süratidir.

Geminin hızı ve yakıt tüketimi arasında bulunan doğrusal olmayan ilișki nedeniyle, yavaș seyreden bir gemi, hızlı giden bir gemiye oranla daha az yakıt tüketecek ve daha az gaz salınımında bulunacaktır. Bu yüzden sürat azaltılması hem yakıt tüketimini hem de salınım miktarını aynı anda azaltabilecek bir araç olarak görülmektedir ve doğal olarak bir kazan-kazan durumu olușturmaktadır. Tarifesiz tașımacılık piyasasında, gemisini spot piyasada çalıștıran ve yakıtı ödeyen gemi sahibi ya da çıplak gemi kiralaması (bare-boat) veya süreli kiralama (time charter) olarak gemiyi kiralayan kiracı, gemi hızını tipik olarak șu parametrelere bağlı olarak seçecektir: (i) yakıt fiyatı ve (ii) piyasadaki navlun oranı. Piyasanın durgun olduğu ya da kriz yașandığı dönemlerde gemiler düșük sürati tercih etmeye meyledeceklerdir. Aynı durum yakıt fiyatlarının arttığı zamanda söz konusudur. Bunun aksine, piyasanın yükseldiği ya da yakıt fiyatlarının düștüğü durumlarda gemiler yüksek sürati tercih edeceklerdir. Benzer durum tarifeli (layner) piyasası için de geçerlidir. Konteyner ve Ro-Ro gemileri ișletmecileri, genellikle bir kısmı kendi gemisi olmak üzere, diğerleri kiralanmıș gemilerden olușan karıșık türde filolar çalıștırmaktadır. Her iki durumda da yakıt layner firması tarafından ödenmektedir. İșletmeci, tașıtana ödettirdiği bedeli piyasa koșullarına göre ayarlarken gelirini tașıtan sayısının çokluğu üzerinden sağlamaktadır. Layner filolarında da, aynı tarifesiz tașımacılıkta olduğu gibi, yakı† fiyatlarının yüksek olduğu ya da piyasanın durgun olduğu durumlarda filoların sürati yavașlamaya meyledecektir (Wen ve diğerleri, 2017). 


\subsection{Gemi İ̦̦letim Maliyeti (Running Cost)}

Bir geminin ișletim maliyetlerinin toplamı, [toplam seyir süresi $X$ geminin 1 günlük ișletim maliyeti] formülü yardımıyla hesaplanır. Gemi ile yük tașıma alanında kullanılan yerleșik uygulamalarda munzam gider hesabı yapılırken, o yıl için bütçeye konulmuș olan munzam masrafların 365'e bölünmesiyle elde edilen miktar geminin günlük ișletim maliyeti olarak kabul edilir. Sefer maliyeti bulunurken de, hesaplanmıș olan bu günlük ișletim gideri geminin seferde geçirdiği gün sayısıyla çarpılarak sefer maliyetini olușturan diğer kalemlere eklenir. Bu giderlere geminin bakım tutum, sigorta, personel giderleri, haberleșme ve diğer (ofis, kırtasiye, su, vb.) giderler dâhil edilir.

\section{Gemi Sefer Maliyet Hesaplarına Yönelik Örneklem}

Örneklem maksadiyla bir denizcilik ișletmesine ait tanker gemisinin aynı rota üzerinde, aynı iki liman arasında yaptığı üç farklı sefere ilișkin sefer maliyeti verileri kullanılmıștır. Söz konusu gemi 19000 DWT'li olup asfalt türevi yükleri tașımaktadır. Tarifeli (layner) tașımacılık yapan ve time charter (zaman esaslı gemi kiralama)'da kirada olan bu gemi tașıdığı özel yüke bağlı olarak çok yüksek sıcaklıklarda (200 derece üstü) yükleri elleçleme ve tahliye etme kabiliyetinde olduğu için geminin kira bedeli yüksektir. Çalıșığı hattın gereği olarak her bir seferde boğaz geçiși yapmakładır.

Geminin farklı zamanlarda aynı limanlara gerçekleștirdiği üç seferine ilișkin bilgiler Tablo 1'de sunulmuștur. Tablo 1'de görüldüğü üzere geminin üç farklı seferde kat ettiği mesafeler birbirine çok yakındır. Geminin sefer süresince kullandığı ortalama hızları 10 knot civarında olup seyir süreleri birbirine çok yakındır. Seferin toplam süresinin ise 40 saat civarında farklılık gösterdiği görülmektedir. Uzun bir seyir için normal sayılabilecek olan bu farklılığın toplam mesafenin 300 mil olduğu bu seyirler için yüksek olduğu söylenebilir. Bu farklılık limanlardaki operasyon ve demirde bekleme sürelerinden kaynaklanmaktadır. 


\section{Tablo 1: Sefer bilgileri}

\begin{tabular}{|c|c|c|c|}
\hline Mesafe (Deniz mili) & 303,8 & 305,2 & 308 \\
\hline Ortalama Hız (knot) & 10 knot & 10,3 & 10.3 \\
\hline Sefer süresi & $\begin{array}{c}4 \text { gün } 18 \text { saat } 12 \\
\text { dakika }\end{array}$ & $\begin{array}{c}3 \text { gün } 17 \text { saat } 00 \\
\text { dakika }\end{array}$ & $\begin{array}{c}5 \text { gün } 9 \text { saat } 24 \\
\text { dakika }\end{array}$ \\
\hline Yükleme liman süresi & $\begin{array}{c}1 \text { gün } 16 \text { saat } 24 \\
\text { dakika }\end{array}$ & $\begin{array}{c}1 \text { gün } 11 \text { saat } 00 \\
\text { dakika }\end{array}$ & $\begin{array}{c}2 \text { gün } 11 \text { saat } 42 \\
\text { dakika }\end{array}$ \\
\hline Tahliye liman süresi & $\begin{array}{c}1 \text { gün } 10 \text { saat } 54 \\
\text { dakika }\end{array}$ & $\begin{array}{c}0 \text { gün } 17 \text { saat } 42 \\
\text { dakika }\end{array}$ & $\begin{array}{c}1 \text { gün } 05 \text { saat } 24 \\
\text { dakika }\end{array}$ \\
\hline Bekleme süresi(Demir) & 8 saat 42 dakika & 6 saat 36 dakika & $\begin{array}{c}0 \text { gün } 10 \text { saat } 12 \\
\text { dakika }\end{array}$ \\
\hline $\begin{array}{l}\text { Seyir süresi (manevra } \\
\text { süreleri dâhil) }\end{array}$ & $\begin{array}{c}1 \text { gün } 6 \text { saat } 24 \\
\text { dakika }\end{array}$ & $\begin{array}{l}1 \text { gün } 5 \text { saat } 42 \\
\text { dakika }\end{array}$ & $\begin{array}{c}1 \text { gün } 6 \text { saat } 06 \\
\text { dakika }\end{array}$ \\
\hline
\end{tabular}

Tablo 2'de her bir seferi olușturan seyir, demir, yükleme/tahliye limanlar ve geminin manevralarına ilișkin fuel oil (fo) ve dizel oil (do) miktarları ayrı ayrı verilerek karșılaștırılmıștır. Ayrıca, her bir sefer dönemi için gemi yakıının șirkete maliyet fiyatları verilmiștir.

\section{Tablo 2: Sefer bașına tüketilen yakıt miktarları karșılaștırması}

\begin{tabular}{|l|c|c|c|}
\hline Yakıt tüketimleri & Sefer No: 1 & Sefer No:2 & Sefer No:3 \\
\hline Seyir & 17,81 fo / 0,94 do & 18,4 fo/ 3,114 do & 18,8 fo /0,68 do \\
\hline Demir & 0,86 do & 0,90 do & 0,81 do \\
\hline Yükleme limanı & 5,195 do & 4,75 do & 7,65 do \\
\hline Tahliye limanı & 5,295 do & 3,15 do & 6,025 do \\
\hline Manevra & 1,4 fo $/ 0,48$ do & 0,947 fo / 0,22 do & 0,47 fo / 0,33 do \\
\hline Yakıt fiyatı ( ifo) & $318 \$$ & $412 \$$ & $420 \$$ \\
\hline Yakıt fiyatı (mgo) & $564 \$$ & $585 \$$ & $549 \$$ \\
\hline Toplam yakıt maliyeti & $13310 \$$ & $15069 \$$ & $16600 \$$ \\
\hline
\end{tabular}

Seferde geminin yaptığı sürate, geminin maruz kaldığı dıș etkiler üzerinden tüketilen yakıt miktarına doğrudan etkisi bulunan deniz ve hava koșullarına ilișkin özet bilgi Tablo $3^{\prime}$ de verilmiștir. Seyirler boyunca rüzgâr genellikle kuzey ve kuzey doğu yönünden seyir yapan gemiyi yavașlatacak șekilde esmiștir. Deniz durumu ise geminin seyrine engel olmayacak seviyede seyretmiș buna karșın üç numaralı sefer deniz ve rüzgâr açısından en dezavantajlı șartlara sahip olmuștur. 
Tablo 3: Seyir süresine ilișkin rüzgâr ve deniz durumu

\begin{tabular}{|l|c|c|c|c|}
\hline & & Rüzgâr Yönü & Rüzgâr Șiddeti & Deniz Durumu \\
\hline \multirow{2}{*}{ Sefer No: 1} & Gün & N & 3 & 2 \\
\cline { 2 - 5 } & gün & N & 3 & 2 \\
\hline Sefer No: 2 & Gün & NE & 3 & 2 \\
\hline & gün & NE & 3 & 2 \\
\hline Sefer No: 3 & Gün & N & 5 & 4 \\
\hline & gün & N & 5 & 4 \\
\hline
\end{tabular}

Tablo 4 ise üç farklı sefere ilișkin sefer giderleri toplam beș farkIı kalem altında listelenerek mukayese edilmiștir. Seferlik giderler incelendiğinde yakıt giderinin en yüksek maliyet kalemini, bununla birlikte seferlik gemi ișletim maliyetinin personel maliyet kalemini de içermesi nedeniyle diğer en yüksek maliyeti olușturduğu görülmektedir.

Tablo 4: Üç farklı sefere ilișkin sefer gideri karșılaștırma tablosu (birimler Amerikan dolarıdır.)

\begin{tabular}{|l|l|c|c|c|}
\hline & Seferlik giderler & Sefer No:1 & Sefer No:2 & Sefer No:3 \\
\hline \multirow{4}{*}{ Liman Giderleri } & Yükleme liman giderleri & 3900 & 3900 & 3900 \\
\cline { 2 - 5 } & Tahliye liman giderleri & 5700 & 5700 & 5700 \\
\hline Boğaz kanal geçișleri & 1730 & 1730 & 1730 \\
\hline Yakıt gideri & 13310 & 15070 & 1660 \\
\hline \multirow{2}{*}{ Navlun komisyonu $(\% 2,25)$} & 3110 & 1770 & 3175 \\
\hline \multirow{4}{*}{$\begin{array}{l}\text { Seferlik gemi ișletim } \\
\text { maliyeti }\end{array}$} & Bakım (yıllık bakım masrafı) & 1400 & 1090 & 1550 \\
\cline { 2 - 5 } & Sigorta & 1540 & 1360 & 1745 \\
\cline { 2 - 5 } & Personel maașı & 14750 & 11580 & 16045 \\
\cline { 2 - 5 } & Haberleșme & 250 & 250 & 250 \\
\cline { 2 - 5 } & Ceșitli (ofis, kırtasiye, su) & 195 & 190 & 195 \\
\hline & TOPLAM & $\mathbf{4 9 1 7 5}$ & $\mathbf{3 9 1 0 0}$ & $\mathbf{4 7 6 0 0}$ \\
\hline
\end{tabular}

\section{Bulgular ve Değerlendirme}

Yukarıda sunulan ve gemi sefer maliyetlerini olușturan farklı kalemler ve etkiler incelendiğinde bunlardan bir kısmının kontrol edilebilir bir kısmının da bağımsız değișken olduğu görülmektedir. Gemi günlük ișletim bedeli (Daily Running Cost), hava ve deniz koșulları, yakıın birim fiyatı, boğaz ve liman hizmetleri rüsumları kontrol edilemez değișkenlerdir. Buna karșılık, gemi sürati, kargo miktarı ve en az onun kadar 
önemli olan kargo çeșitliliği ise gemi sefer maliyetinin kontrol edilebilir değișkenleridir.

Geniș perspektiften bakıldığında geminin günlük ișletim bedeli șirket temelinde yapılacak çalıșmalarla belirli oranda azaltılabilir. Ancak bu çalıșma kapsamında sunulan veriler incelendiğinde, bu maliyetlerde küçük değișiklikler olduğu görülmektedir. Bu durum günlük ișletim bedelinin bağlı olduğu faktörlerden (personel gideri, bakım-tutum gideri vs.) bazılarında değișiklik olduğunu göstermektedir. Yine de, farklılıklar her üç seferin sefer maliyetine yansıtılmıș yapılan karșılaștırmada sefer maliyetine etkileri dâhil edilmiștir.

Özellikle layner çalıșan gemiler yaptıkları her seferde aynı rotaları izledikleri için rotaları üzerinde bulunan boğaz/kanalları kullanmak durumundadırlar. Bu tür yerlerden geçiște alınacak hizmetler (kılavuzluk, römork ve fener ücretler vs.) ve bunların karșılığında ödenecek ücretler otoritelerce belirlenmektedir. Geminin geçișe ilișkin ödenen bu tür ücretler doğrudan sefer maliyetine yansıdığı gibi gemi ișletmesi tarafından söz konusu maliyetlere hiçbir müdahalede bulunulamaz. Bu açıdan bakıldığında bunlar kontrol edilemeyen sabit giderlerdir.

Geminin limana giriș, liman içi operasyonları ve liman çıkıș ișlemleri süresince sağlanan hizmetler de ücrete tabidir. Tek bir gemi üzerinden bakıldığında bu ücretler otoriteler tarafından belirlenmiș sabit ücretleri içermekte ve yine doğrudan sefer maliyetlerine yansımaktadır. Tablo 5'de de gösterildiği üzere bunlar sabit ve gemi ișletmesi tarafından kontrol edilemeyen giderlerdir.

Hava ve deniz koșullarının sefer maliyeti üzerine olumsuz etkisi ise bir yöntem olarak rota değișiklikleri (hava rotalama) ile azaltılabilir. Ele alınan üç seferde bu usul kullanılmamıștır. Bunun nedeni örneklem gemisinin layner tașımacılık yapması ve sefer süresince kat edilen mesafenin görece olarak kısa olması (300 deniz mili) sebebiyle bu yöntemin uygulanabilir olmayıșıdır. Ancak, inceleme kapsamında deniz ve hava koșullarının sefer maliyetine hiç etkisi olmadığından söz edilemez. Doğal olarak gemiyi olumsuz etkileyen bu çevresel koșullar gemini direncini ve dolayısıyla sefer boyunca tükettiği toplam yakıt miktarını artırmakta ve sefer maliyetini olumsuz etkilemektedir.

Sefer süresince harcanan yakıt miktarını doğrudan etkileyen en önemli iki faktör geminin sürati ve gemiye etkiyen harici kuvvetlerdir. İncelemesi yapılan seferlerde geminin iki ve üç numaralı seferdeki or- 
talama hızı aynı iken (10.3 knot) (Tablo 1) ortaya çıkan yakıt miktarı farklılığını hava ve deniz koșulları ile açıklamak mümkündür. Tablo 3'de sunulan sefer esaslı hava ve deniz koșulları incelendiğinde üç numaralı seferin daha zorlu çevresel koșullarda yapıldığı görülmektedir. Bilindiği üzere olumsuz çevresel koșullar doğrudan geminin su içerisindeki sürtünme ve güverte yüksekliği nedeniyle de negatif yelken etkisiyle geminin ana tahrik sisteminin daha fazla güç harcamasına neden olmaktadır. Böyle bakıldığında deniz ve hava koșulları doğrudan tüketilen fuel oil miktarını etkilemektedir. Bu durum Tablo 2'de sunulan seferlerde harcanan fuel oil çizelgelerinde net bir șekilde görülmektedir. Bu durumu sefer bilgilerini gösteren Tablo 1'de de görmek mümkündür. Örneğin, geminin sefer detaylarını (seyir süresi, aynı limanlar arasında kat edilen mesafe ve ortalama hız gibi) sunan Tablo l'de iki numaralı sefer ile üç numaralı seferin ortalama hızları eșit iken toplam fuel oil harcamaları arasında 0.4 ton fark bulunmaktadır. Bu durumun deniz ve hava koșullarının yakıt tüketimi üzerindeki negatif etkisinden kaynaklandığı söylenebilir.

Dikkat çeken diğer bir konu ise bir numaralı seferin ortalama hızının diğer iki sefere göre düșük olmasının seyir yakıt tüketiminin diğerlerinden daha az olmasını sağlamıștır. Bu durum Tablo 1'de sunulan ortalama hızlar ile Tablo 2 'de sunulan sefer yakıt miktarlarının mukayesesinde görülmektedir.

Bunlara karșın, gemi ișletmeleri ve gemi personeli tarafından kontrol edilebilen ve bu nedenle de sefer maliyetlerini düșürebilecek kalemlerin varlığından bahsetmek de mümkündür. Bunların bașında zaman sınırlamasının olmadığı durumlarda seyrin geminin en ekonomik süratine ayarlanması gelir. Bu açıdan bakıldığında geminin boğaz geçiși, liman giriși ve tahliye operasyonu için maruz kalacağı bir zaman baskısı yok ise, yani gemi düșük süratte seyrettiğinde dahi bu üç operasyon aksamadan yapılabiliyor ise, düșük hızları seçmek doğrudan yakıt maliyetini de dolayısıyla da toplam sefer maliyetini azaltabilecektir. Her ne kadar gemi hızının tüketilen yakıt miktarına dolayısıyla sefer bazındaki yakıt maliyetine etkisi olduğu tespit edilmiș olsa da, seferlerin yapıldığı dönemdeki yakıt birim maliyeti de göz ardı edilmemelidir. Yakıt fiyatlarının arttığı dönemlerde doğal olarak yakıt maliyetleri de artacaktır.

Gemi ișletmesi tarafından kısmen de olsa kontrol edilebilir diğer bir faktörü limanda geçirilen süreler olușturmaktadır. Limanda geçirilen süre özellikle tahliye operasyonlarında harcanan zamandan doğrudan 
etkilenir. Bu süreyi doğrudan etkileyen en önemli unsur tașınan yük çeșitliliğidir. Yükün çeșitliliği her bir yük için farklı prosedürler gerektireceğinden hem yükleme hem de tahliye operasyonları için limanda kalma süreleri artacaktır. Varılan limandaki tahliye operasyonu gemi pompaları ile yapıldığı için, her farklı yük çeșidi yeni ayarlamaları gerektirecek, böylelikle de tahliye süresi, dolaylı olarak da limanda kalıș süresi uzayacaktır. Limanda kalınan süre uzadıkça günlük ișletim maliyeti (daily running cost) sabit olmasına rağmen kalınan sürenin uzamasına paralel olarak toplam seferlik gemi ișletim maliyetini artıracaktır. Bununla birlikte, limanda kalınan süre uzadıkça çalıștırılan yardımcı makinalara bağlı olarak ta geminin dizel yakıt tüketimi yükselecektir. Bu durum boğaz ağzındaki geçiș sırası beklemeleri için de geçerlidir. Yukarıda söz edildiği üzere bu sorun geminin hızını öngörülebiliyorsa geçiș zamanına denk gelecek șekilde ayarlanması ile çözülebilir.

Buraya kadar sözü edilen kontrol edilebilir ya da sabit kontrol edilemez gider kalemler, içinde bulunulan koșullara göre karlılığa neden olabileceği gibi kar miktarında bir azalmaya da neden olabilirler. Yukarıda da sözü edildiği gibi yük çeșitliliği ve yükü tahliye etmeden önce tabi tutulacak ișlemler (ısıtma gibi) liman operasyon sürelerini ve dolayısıyla da sefer maliyetini artırmaktadır. Buna çözüm getirecek șekilde gemi ișletmeleri sefer maliyetlerini hesaplarken bu dezavantajları da dikkate alarak navlun miktarını o sefere özel yukarı çekerek karlılıklarını sürdürebilirler.

\section{Sonuç}

Maliyet çözümlemesi yapmayı hedefleyen bu çalıșma, aynı iki liman arasında mesafe ve rota olarak özdeș nitelikte olan ve layner çalıșan bir geminin üç farklı seferine ilișkin giderleri incelemiștir. İnceleme temelde, sefer maliyetlerini olușturan gider kalemlerini büyüklük ve kontrol edilebilirlik açısından inceleyerek, bu maliyetleri en aza, karlılığı ise en fazlaya çıkarabilecek unsurları tespit etmeyi hedeflemiștir. Ortaya çıkarılan sefer giderleri karșılaștırılarak anlamlı sonuçlar elde edilmeye çalıșılmıș ve ortaya çıkarılan farklılıklar çözümlenmiștir. Buna paralel olarak, sefer giderlerinin hangilerinin sabit ya da değișken olduğuna, bunlardan hangilerinin ise kontrol edilebilir nitelikte olduğuna da dikkat edilmiștir.

Eș nitelikteki seferler için yapılan hizmet alımları, harç, resim ve vergiler ile piyasalardaki gemi yakıtı fiyatı sabit ve kontrol edilemez değișkenler olarak ele alınmıștır. Bir sefer süresince, doğrudan sürate 
bağlı olarak artan yakıt tüketiminin getirdiği maliyet bir seferin en önemli gider kalemlerinden birini olușturmaktadır. Çalıșma kapsamında ele alınan üç farklı seferde aynı gemi çok az farkları olan ortalama süratler kullanmıștır. Bu küçük sürat farklarının aynı oranda doğrudan yakıt maliyetlerine de yansıdığı görülmüștür.

Sefer maliyetlerindeki farklılığın daha çok geminin gerek demirde, gerekse boğaz ağzı gibi bölgelerde atıl olarak beklediği süreler ile limanda kaldığı sürelerden kaynaklandığı tespit edilmiștir. Yük çeșitliliğinden kaynaklanan tahliye sürelerinin uzunluğunun, limanda kalıș süresine doğrudan etki eden unsurların bașında geldiği görülmüștür. Buradan kaynaklanacak maliyet dezavantajının gemi ișletmesi tarafından hesaplanan navlun önerisine doğrudan yansıtılarak ortadan kaldırılabileceği, böylelikle de karlılığın sürdürülebileceği vurgulanmıștır. 


\section{KAYNAKÇA}

Alexandridis, G., Kavussanos, M.G., Kim, C.Y., Tsouknidis, D.A., \& Visvikis, I.D. (2018). A Survey of Shipping Finance Research: Setting The Future Research Agenda. Transportation Research Part E, 115, 164-212.

Alizadeh, A.H., \& Nomikos, N.K. (2012). Ship Finance: Hedging Ship Price Risk Using Freight Derivatives. In W.K., Talley (Ed.), Blackwell Companion to Maritime Economics (pp. 433-451). Wiley-Blackwell.

Altınbuçuk, F. (2000). Liman İdare ve İșletmesi. İstanbul: IMEAK Deniz Ticaret Odası Yayınları, 12, 101.

Altuğ, O. (1974). Deniz Tașıt İșletmelerinde Maliyetler ve Maliyetlerin Yönetim Yönünden İncelenmesi. İstanbul: Marmara Üniversitesi Sosyal Bilimler Enstitüsü.

Arslan, Ö. \& Gürel, O. (2008). Farklı Tip ve Boyutta Gemilerin Seçiminin Bulanık Mantık Yöntemiyle İncelenmesi. Havacılık ve Uzay Teknolojileri Dergisi, 3 (4), 55-60.

Bialystocki, N. \& Konovessis, D. (2016). On the Estimation of Ship's Fuel Consumption and Speed Curve: A Statistical Approach. Journal of; Ocean Engineering and Science, 1, 157-166.

Bursal, N. \& Ercan, Y. (2000). Maliyet Muhasebesi, İlkeler ve Uygulama. İstanbul: Der Yayınları, 8. Basım.

Çatak, C.. (2003). Deniz Ticaret İșletmelerinde Maliyetler ve Gemi Kiralama. Deniz Ulaștırma İșletme Mühendisliği Bitirme Tezi, İstanbul Üniversitesi, Mühendislik Fakültesi.

Çakı, S. (1998). Deniz Ulaștırma İșletmelerinde Maliyetler ve Maliyet Sisteminin Kurulması, Çağdaș Denizcilik Stratejileri İșletme Yönetimi Yaklașımı (pp. 175-186). İzmir: Dokuz Eylül Yayınları.

Downard, J. M. (1982). Running Costs, Ship Management Series. London: Fairplay Publications LTD.

Erol, S. (2013). Denizyolu Tașıma Maliyetlerinin Finansmanında Türev Ürünlerin Kullanımına Yönelik Bir Uygulama. Doktora Tezi, Erzurum: Atatürk Üniversitesi Sosyal Bilimler Enstitüsü.

Erol, S. (2016). Calculating the Unit Voyage Cost in Maritime Transportation: An Implementation Study. International Social Science, Humanity and Education Research Congress (SSHERC-16). July 20-21, Bali (Indonesia).

Eröztürk, S.E. (1985). Deniz Tașımacılığında Acenteliğe Bașlarken. İstanbul: Deniz Nakliyatı T.A.S. Yayını.

Esmer, S., Yılmazer, M., \& Firuzan, A.R. (2005). Gemi İșletim Maliyetlerinde Gider Minimizasyonu. Dokuz Eylül Üniversitesi, Sosyal Bilimler Enstitüsü, 7(3).

Everett C. H., \& Boris, B. (1994). Maritime Engineering Economics and Cost Analysis, Cornell Maritime Press.

Garrison, R.H., \& Noreen, E. W. (2000). Managerial Accounting. The McGraw-Hill Companies, Inc., 9 th Edition. 
Golias, M.M., Saharidis, G.K., Boile, M. , Theofanis, S., V., \& lerapetritou, M.G. (2009). The Berth Allocation Problem: Optimizing Vessel Arrival Time. Maritime Economics \& Logistics, 11 (4), 358-377.

İncaz, S. (2017). Konteyner Hat İșletmeciliğinde Maliyetler. İstanbul: Beta Yayınevi, 2. Basım.

Karcıoğlu, R. (2000). Stratejik Maliyet Yönetimi. Erzurum: Aktif Yayınevi.

Khan, M.R.R., \& Abed, S.Y. (2010). Design and Development of Database Shipping Productivity Management System. Journal of Naval Science and Engineering, 6(3), 55-75.

Notteboom, T.E. (2006). The Time Factor in Liner Shipping Services. Maritime Economics \& Logistics, 8 (1), 19-39.

Okka, O. (2009). Finansal Yönetim Teori ve Çözümlü Problemler. Ankara: Nobel Yayın Dağıım, 3. Basım.

Özdemir, Ö. (2009). Denizyolu Yük Tașımacılığında Maliyetler ve Bir Uygulama. Doktora Tezi. İstanbul: İstanbul Üniversitesi Sosyal Bilimler Enstitüsü.

Rayburn, L. G. (1996). Cost Accounting, Using a Cost Management Approach, Irwin, 6th edition.

Ronen, D. (201 1). The Effect of Oil Price on Containership Speed and Fleet Size. Journal of the Operational Research Society, 62 (1), $211-216$.

Stopford, M. (1997). Maritime Economics. Routledge.

Stopford, M. (2009). Maritime Economics, Routledge, Oxford. third ed.

Trivedi, S. M. (2010). An Analysis of Financial Performance of State Road Transport Corporation in Gujarat. Ph.D. Thesis. Rajkot: Saurashtra University.

UNCTAD (2017). United Nations Conference on Trade and Development. Review of Maritime Transport.

Wang, S., \& Meng, Q. (2012). Sailing Speed Optimization for Container Ships in a Liner Shipping Network. Transportation Research, Part E, 48, 701-714.

Wang, S., Gao, S., Tan, T., \& Yang, W. (2019). Bunker Fuel Cost and Freight Revenue Optimization for a Single Liner Shipping Service. Computers and Operations Research, 111, 67-83.

Wen, M., Pacino, D., Kontovas, C.A., \& Psaraftis H.N. (2017). A Multiple Ship Routing and Speed Optimization Problem Under Time, Cost and Environmental Objectives. Transportation Research Part D, 52, 303-321. 
